\title{
Desconstruir a Corrupção: o Papel do Legislador, Príncipe e Soberano. A Análise do Caso no Pensamento de Jean-Jacques Rousseau.
}

Adriano Eurípedes Medeiros Martins*

\section{Resumo}

DOI 10.20399/P1982-999X.2016v1n2pp04-15

Não há Estado sem os indivíduos. Para Rousseau a construção do Estado requer a participação direta dos cidadãos. A participação ativa dos cidadãos resultará na expressão da vontade geral. É a vontade geral que, via pacto social, dará vida e união ao Estado. O Estado é um projeto de corpo político. A participação ativa dos cidadãos com vistas a impedir a corrupção e a dissolução da sociedade remete à concepção da soberania popular. Nessa modalidade de soberania, os cidadãos seriam capazes de construir e manter os fundamentos da sociedade civil. Rousseau, como um contratualista, pensa a sua época e as soluções políticas para os problemas reais de seu tempo. Portanto, é desse cenário entre a teoria e a prática, que Rousseau partirá para configurar a distinção e a relação desse importante tripé: soberano, Legislador e príncipe.

Palavras-chave: Jean-Jacques Rousseau; Legislador; Soberano; Renaturação.

\begin{abstract}
There is no state without subjects. For Rousseau state-building requires the direct participation of citizens. The active participation of citizens will result in the expression of the general will. It is the general will that via social pact, give life and unity to the state. The state is a political body design. The active participation of citizens in order to prevent corruption and dissolution of the company refers to the conception of popular sovereignty. In this mode of sovereignty, citizens would be able to build and maintain the foundations of civil society. Rousseau, as a contractualist, thinks his time and political solutions to the real problems of his time. So it is this scenario between theory and practice, which Rousseau will start to set up the distinction and the relationship of this important tripod: Sovereign, Legislator and Prince.
\end{abstract}

Key-words: Jean -Jacques Rousseau; Legislator; Sovereign; Renaturation.

Antes de adentrarmos nas especificidades da relação e distinção entre o Legislador, o príncipe e o soberano, abordaremos uma outra relação também importante na configuração do corpo político. Trata-se da diferenciação entre o Estado e o governo. Tal distinção é essencial para delimitarmos o lugar do Legislador no processo de renaturação ${ }^{1}$. Para Jean-Jacques Rousseau, cidadão de Genebra, tal distinção se configura nos seguintes termos:

Há uma diferença essencial entre esses dois corpos: o Estado existe por si mesmo e o Governo só existe pelo soberano. Desse modo, a vontade dominante do príncipe só é, ou deveria ser, a vontade geral ou a Lei, e sua força não é senão a força pública nele concentrada: desde que deseje derivar de si mesmo qualquer ato absoluto e independente, começa a afrouxar-se a ligação do todo. Enfim, se porventura tivesse o príncipe uma vontade particular mais ativa do que a do soberano e, para obedecer a essa vontade particular, se utilizasse da força pública de que dispõe, de modo que se teriam, por assim dizer, dois soberanos,

\footnotetext{
* Doutor em Filosofia. Professor de Filosofia do Instituto Federal do Triângulo Mineiro (IFTM), Graduado em Filosofia pela Universidade Federal de Uberlândia (UFU). Mestre e Doutor em Filosofia pela Universidade Federal de Minas Gerais (UFMG). Pós-doutorando em Filosofia pela UFU.

${ }^{1}$ Para Rousseau o homem civilizado está corrompido. Mas, tal situação, dada a perfectibilidade humana, pode ser modificada. E a saída da corrupção para uma situação oposta é designada pelo autor de 'renaturação'.
} 
um de direito e outro de fato, imediatamente a união social desapareceria e dissolver-se-ia o corpo político. ${ }^{2}$

Essa é uma passagem singular, pois nela os principais temas do presente texto aparecem num ordenamento importante e consequente; além de abarcar a gênese e o telos das instituições políticas e sociais que se vai construir.

Não há Estado sem os indivíduos. Para Rousseau, a construção do Estado requer a participação direta dos cidadãos. A participação ativa dos cidadãos resultará na expressão da vontade geral. É a vontade geral que, via pacto social, dará vida e união ao Estado $^{3}$. Dada essa maneira de construir seus argumentos, podemos deduzir que o Estado aqui tratado é um projeto de corpo político. Até porque essa participação ativa dos cidadãos com vistas a impedir a corrupção e a dissolução da sociedade remete à concepção da soberania popular. Nessa modalidade de soberania, os cidadãos seriam capazes de construir e manter os fundamentos da sociedade civil. Apesar de parecer uma utopia, defendemos que essa proposta não é uma mera idealização do Genebrino. Trata-se de uma proposta ou melhor, de um projeto. E como tal, ele poderá ser de difícil implementação, mas não irrealizável. Ademais, Rousseau, como um contratualista, pensa a sua época e as soluções políticas para os problemas reais de seu tempo. Portanto, é desse cenário entre a teoria e a prática ${ }^{4}$, que Rousseau partirá para configurar a distinção e a relação desse importante tripé: soberano, Legislador e príncipe. Comecemos, então, pelo soberano.

No quadro geral, a soberania é um elemento basilar no pensamento políticofilosófico de Rousseau. A soberania nunca será determinada por outra coisa que não a vontade geral ${ }^{5}$, sendo que os demais poderes não deverão passar de meras delegações dessa soberania ${ }^{6}$ - a qual não é senão a vontade do corpo do povo e tendendo sempre ao interesse geral. Caso contrário, "não passa de uma vontade particular ou de um ato de magistratura, quando muito, de um decreto" 7 . Há, de um lado, a soberania e, do outro, as delegações ou decretos emanadas dela. Consequência preliminar: o poder legislativo é soberano; ao passo que, o poder executivo será uma delegação ou um decreto.

Ao poder executivo competirá, essencialmente, organizar e dar movimento ao governo. Ressalvamos que o Genebrino não é partidário da concepção que divide os poderes em dois, três ou quatro esferas de ação distintas e complementares. No caso especifico dessa demanda entre o legislativo e o executivo, Derathé argumenta que " $a$ separação dos poderes não tem outra finalidade senão a de assegurar o equilíbrio e a mútua limitação dos mesmos. Não se trata, de modo algum, de dar alguma independência ao executivo" 8 . Até porque, nesse Estado soberano, o executivo é regido pelas leis. Logo, o que há é um único poder e suas várias emanações ou decretos.

Como vimos, a expressão da soberania é obtida, unicamente, através da vontade geral. Posto que apenas a totalidade do corpo político possa legitimar aquilo que se

\footnotetext{
${ }^{2}$ ROUSSEAU, Jean-Jacques. Du contrat social. In: GAGNEBIN, Bernard; RAYMOND, Marcel. (orgs.). Oeuvres Complètes. Paris: Pléiade-Gallimard, 1995, v. 3, p. 399.

${ }^{3}$ Cf. Ibidem, p. 378.

${ }^{4}$ Segundo Machado, "o governo dos monarcas do século XVIII caracterizava-se exatamente por uma total confusão da vontade e interesses particulares da pessoa real com os objetivos e o exercício do poder do Estado". (MACHADO apud ROUSSEAU, Jean-Jacques. Textos Escolhidos/Rousseau. Trad. de Lourdes Santos Machado. São Paulo: Nova Cultural, 2000, p. 141).

5 "De par sa nature, la souveraineté est uniquement et essentiellement volonté". (DERATHÉ, R. JeanJacques Rousseau et la science politique de son temps. Paris, Vrin, 1970, p. 293. (grifo do autor)).

${ }^{6}$ Segundo Derathé, “on sait que pour lui [Rousseau] 'l'essence de la souveraineté consiste dans la volonté générale". (Ibidem., p. 252).

${ }^{7}$ ROUSSEAU, 1995 , p. 369.

${ }^{8}$ DERATHÉ, 1970, p. 301. (Tradução nossa).
} 
expressa por meio da vontade geral. Essa totalidade não precisará construir um consenso, basta que nenhuma das partes seja ignorada ou esquecida. Desse modo, ficaria assegurada a união e o compromisso dos cidadãos com a sociedade. Por isso se faz necessária a observância da seguinte premissa: "Cada um de nós põe em comum sua pessoa e todo o seu poder sob a direção suprema da vontade geral, e recebemos, enquanto corpo, cada membro como parte indivisível do todo"9. Essa passagem é importante para mostrar como a vontade geral constrói o corpo político ou o Estado ${ }^{10}$. E este não é um Estado qualquer. Temos aqui o Estado soberano e a sua fundação alicerçada num sistema de leis. Fundação em sentido duplo, isto é, como origem e como fundamento. A gênese e o apoio do Estado soberano estão na expressão da vontade política dos cidadãos, ou seja, na vontade geral.

Considerando que a vontade geral é a vontade política dos cidadãos, não poderíamos admitir que o Estado soberano fosse um ente político totalitário? Preliminarmente sustentamos que, soberano e totalitário não são sinônimos. Consideremos, por exemplo, o que diz Talmon a respeito das características de um Estado totalitário:

\begin{abstract}
Impôs-se um modelo fixo, austero, universal, dos sentimentos e da conduta, com o objetivo de criar o homem de uma só peça, sem contradições, sem força centrífuga nem desejos antissociais. O objetivo era criar cidadãos que quisessem somente a vontade geral $\mathrm{e}$ que, desse modo, fossem livres, em lugar de que cada homem constituísse uma entidade em si mesmo, atormentado por paixões egoístas e, portanto, escravizado. ${ }^{11}$
\end{abstract}

Em alguma medida a caracterização do intérprete de uma sociedade monolítica é razoável, e ela lembra o risco de interpretarmos a vontade geral como uma força visando impor uma configuração única ao comportamento dos cidadãos dentro do que poderíamos chamar de Estado total. Mas, antes de associarmos o pensamento do Genebrino ao que foi apontado pelo estudioso como sendo o projeto de uma sociedade total, é preciso notar que a premissa inicial, que trata o Estado soberano como uma "imposição", merece uma análise mais meticulosa.

Uma vez que a soberania é indivisível ${ }^{12}$, ela é totalidade, não totalitária. Assim, para compreender corretamente o pensamento do Genebrino, temos de reforçar a distinção entre totalitário e totalidade. O Estado soberano apoia-se na totalidade, pois, "a soberania é um atributo que pertence a totalidade, ao corpo da nação, sem que se tenha o direito de aliená-la ou transmiti-la"13. Por não ser totalitária, a vontade geral não ignora a vontade particular dos indivíduos ${ }^{14}$ e nem poderia fazê-lo. Ela se aplica aos aspectos essenciais da constituição da unidade do corpo político, mas isso não quer

\footnotetext{
${ }^{9}$ ROUSSEAU, 1995, p. 361.

10 “Qu'est-ce qui fait que l'État est un? C'est l'union de ses membres. Et d'où naît l'union de ses membres ? De l'obligation qui les lie". (ROUSSEAU, 1995, p. 806).

${ }^{11}$ TALMON. Jacob Leib. Los Orígenes de la democracia totalitária. Madrid: Aguillar, 1956, p. 42.

12 "Par la même raison que la souveraineté est inaliénable, elle est indivisible. Car la volonté est générale, ou elle ne l'est pas; elle est celle du corps du peuple ou seulement d'une partie. Dans le premier cas cette volonté déclarée est un acte de souveraineté et fait loi. Dans le second, ce n'est qu'une volonté particulière, ou un acte de magistrature, c'est un décret tout au plus". (ROUSSEAU, 1995, p. 369).

${ }^{13}$ DERATHÉ, 1970, p. 267. (tradução nossa).

${ }^{14}$ É da natureza da vontade geral expressar o que há de comum nos interesses de todos os indivíduos que formam o Estado. Por isso, ela não pode ser algo alheio à vontade de cada um. Mas, também não quer dizer que toda e qualquer deverá ser traduzida em interesse comum, pois aí poderíamos ter um quadro de anarquia social. (Cf. ROUSSEAU, 1995, p. 368).
} 
dizer que sua função seja criar um Estado monolítico. Ao contrário, ela encontra nos princípios mesmos que a guiam, a saber, a liberdade e a igualdade os limites para sua expressão.

Desse concerto entre povo, vontade e Estado é que surgirão as leis de interesse geral $^{15}$. Ou como afirma Bignotto, "o interesse comum é o único verdadeiramente visado pela vontade geral" 16 . Sendo assim, diferentemente do modelo totalitário, tanto a liberdade como a igualdade seriam preservadas, valorizadas e expandidas por um Estado soberano que agiria estritamente em conformidade com as leis civis. Além disso, o Estado totalitário existe em função do abuso da vontade geral, tal situação reforçaria a desigualdade entre os homens. Já o Estado soberano, inversamente, existiria em função do comprometimento dos cidadãos com o corpo político, o que seria fundamental para que a renaturação se tornasse uma realidade social e política. Até porque não haverá renaturação se não se preservar a soberania e a liberdade dos membros do corpo político.

Por não estar vinculada a nenhuma forma de totalitarismo, a vontade geral não elimina nem a individualidade (vontade particular) nem suprime a liberdade, ao contrário, servirá como garantia para ambas. Vale destacar que é daí é que surgirá a figura do cidadão. Ao agir em conformidade com a vontade geral, o indivíduo se reconhece como membro do corpo político e torna-se cidadão. Enquanto cidadão visará sempre ao bem comum. Por isso que o Estado de leis e a cidadania deverão caminhar juntos e em equilíbrio. Assim, não há que se temer o abuso do poder soberano. Todos aqueles que formam o corpo político participam da autoridade soberana, sendo desse modo cidadãos. Por outro lado, todos estão também submetidos às leis do Estado, ou seja, às convenções entre os que participam do pacto. Nesse momento, o cidadão tornase súdito ${ }^{17}$. Dessa ambivalência "obedecer-a-si-mesmo/mandar-em-si-mesmo", preserva-se a liberdade e garante-se a igualdade de condições entre os membros da coletividade. Por isso, Derathé sustenta que "A igualdade torna-se, assim, a base do sistema e a verdadeira garantia dos direitos de cada um"18. Aí, ao assumir o compromisso com o corpo coletivo cada um estaria assumindo um compromisso consigo mesmo. Logo, o Genebrino não concebe que esse poder soberano seja dividido ou delegado. O poder soberano expressa o compromisso do cidadão com o todo. É esse comprometimento que não poderá ser transferido ou segmentado a outrem.

Uma das condições para que esse referido interesse geral seja alcançado está no equilíbrio entre Estado e Governo ${ }^{19}$. Por essa razão, o soberano, o Príncipe e o Governo deverão sempre caminhar juntos. Juntos, mas, com atribuições institucionais bem claras e distintas. Nesse sentido que o Genebrino sustentará que, "só a vontade geral pode dirigir as forças do Estado de acordo com a finalidade de sua instituição, que é o bem comum" 20 . Uma vez que o Estado, derivado do pacto social e da vontade geral, é livre e

\footnotetext{
${ }^{15}$ Em linhas gerais, "la volonté particuliere tend par sa nature aux préférences, et la volonté générale à l'égalité". (ROUSSEAU, 1995, p. 368).

${ }^{16}$ BIGNOTTO, Newton. As aventuras da virtude: as ideias republicanas na França do século XVIII. São Paulo: Companhia das Letras, 2010, p. 170.

17 "A l'égard des associés ils prennent collectivement le nom de Peuple, et s'appellent en particulier citoyens comme participants à l'autorité souveraine, et sujets comme soumis aux lois de l'Etat.". (ROUSSEAU, 1995, p. 362).

${ }^{18}$ DERATHÉ, 1970, p. 303. (tradução nossa).

${ }^{19}$ Cf. ROUSSEAU, 1995, p. 399.

${ }^{20}$ Ibidem, p. 368.
} 
soberano $^{21}$, passaremos a abordagem da configuração e da finalidade do executivo ou do governo em relação a esse Estado soberano.

Rousseau qualifica o governo nos seguintes termos: "Chamo, pois, de Governo ou administração suprema o exercício legítimo do poder executivo, e de príncipe ou magistrado o homem ou o corpo encarregado dessa administração" 22 . Sob a égide do poder legislativo, o poder executivo desenvolverá as ações cotidianas com vistas à consecução do interesse geral. Ou seja, o Estado sobrepõe e determina o governo. Se o contrário ocorrer, caminhar-se-á para uma usurpação do poder, cuja consequência seria a constituição de um Estado tirânico.

Mais adiante trataremos de alguns aspectos relacionados à tirania e a usurpação do governo. Por ora, passaremos a abordagens dos possíveis modelos de governo. Basicamente temos três modelos de governo ${ }^{23}$ : democracia, aristocracia e monarquia ${ }^{24}$. Esses três modelos podem, ainda, assumir configurações mistas. Tal como, por exemplo, uma monarquia parlamentarista. Essa questão do modelo de governo traz consigo um outro aspecto importante: a natureza dos povos e a sua receptividade às leis. Daí Cassirer colocar-nos diante da seguinte questão: "qual é a forma de Estado que, em virtude da sua natureza, realiza em si, da maneira mais perfeita, o puro domínio da lei?"25. Destacamos que, desde que o interesse geral seja efetivamente garantido, o modelo político-social, qualquer que seja, refletirá apenas a particularidade dos membros do pacto social. Em suma, num Estado de leis e com governo constituído, o que se mostrará fundamental é justamente a existência de leis e o respeito às mesmas.

Conexo a isso temos que, "não sendo a Lei mais do que a declaração da vontade geral, claro é que, no poder legislativo, o povo não possa ser representado, mas tal coisa pode e deve acontecer no poder executivo, que não passa da força aplicada à Lei" ${ }^{\prime 2}$. Nesse sentido, o governo, o príncipe e os magistrados têm sua existência devido a necessidade de se executar aquilo que prescreve a vontade geral; jamais para fazer prevalecer os interesses parciais ou a vontade particular desses mesmos que dirigem o governo ${ }^{27}$. Nesse sentido, quem efetivamente governa é o soberano, isto é, a vontade geral dos membros do corpo político. Até por isso, " $o$ governo não tem poderes senão aqueles que lhe são dados pela lei" ${ }^{28}$. Caso isso não ocorresse, teria-se um flagrante ato contra a liberdade e a igualdade dos cidadãos. Portanto, segundo Goldschmidt, "a instituição dos governos está em conformidade com $o$ direito, além de ser o melhor possível"29. É preciso ter claro que esse "melhor possível" remete ao interesse geral. Pois, numa sociedade em que o executivo

\footnotetext{
${ }^{21}$ Rousseau argumenta que, “il importe donc pour avoir bien l'énoncé de la volonté générale qu'il n'y ait pas de société partielle dans l'Etat et que chaque Citoyen n'opine que d'après lui". ROUSSEAU, 1995, p. 399).

22 Ibidem, p. 396. (grifos do autor).

${ }^{23}$ Cf. ROUSSEAU, 1995, p. 402-4.

${ }^{24}$ Esclarecemos que no caso da monarquia, esta não será hereditária, mas eletiva. O mesmo vale para os demais modelos. O importante é assegurar que não seja criada uma classe com certos privilégios, pois isso atentaria contra a igualdade dos cidadãos. Ademais, ao povo competirá a difícil tarefa de zelar pelo interesse geral. E mais ainda, é importante se salvaguardarem para que os membros do executivo não se tornem "Senhores" e os demais apenas meros "súditos".

${ }^{25}$ CASSIRER, Ernst. A questão Jean-Jacques Rousseau. São Paulo: Editora Unesp, 1999, p. 65.

${ }^{26}$ ROUSSEAU, 1995, p. 430.

27 "The establishment of a government is a 'complex act' really 'composed of two others, namely the establishment of the law, and the execution of law'”. (MASTERS, Roger D. The Political Philosophy of Rousseau. Princeton: Princeton University Press, 1968, p. 336).

${ }^{28}$ ROUSSEAU, 1995, p. 840. (tradução nossa).

${ }^{29}$ GOLDSCHMIDT, Victor. Anthropologie et politique: les principes du système de Rousseau. Paris, Vrin, 1983, p. 679. (tradução nossa).
} 
predomina sobre o legislativo, esse pretenso "melhor possível" atentaria contra a igualdade, a liberdade e as leis civis. Ou seja, deixaria de ser uma emanação do poder legislativo para tornar-se uma usurpação.

Mas, e se o governo e suas demandas executivas se sobreporem às decisões do legislativo? Apesar disto ser uma constante na história das sociedades civilizadas, sabemos que tal coisa não deverá acontecer num corpo político bem ordenado. Por essa razão Spitz alerta que

O poder executivo (...) é necessário para dar vida e movimento ao corpo político. Sem ele, o povo seria, por sua vez, soberano e magistrado, e essa confusão seria muito prejudicial, pois iria acabar confundindo os atos que emanam dele, como um poder soberano, daqueles que ele realiza como magistrado, e que apenas dizem respeito a objetos particulares. ${ }^{30}$

Se tal convergência ou confusão entre o executivo e o legislativo ocorrer, teremos um quadro prejudicial à totalidade do corpo político, podendo resultar, até mesmo, num cenário de opressão. Posto que, poderíamos ter a vontade particular do magistrado ou príncipe - poder executivo - sobrepondo-se à vontade geral - poder legislativo ${ }^{31}$. Naturalmente, esse é um ambiente de grave perigo para a liberdade e a igualdade dos próprios cidadãos. Logo, o povo, apesar de ser soberano, não deverá exercer todo tipo de poder no interior do Estado. Daí, Rousseau advogar pela alienação ou transferência do poder executivo aos magistrados ou ao príncipe.

Reforçamos que a soberania tem duas características principais e que explicam o fato de, acima dela, não pairar nada. Rousseau parte da seguinte premissa: a soberania, tal como a vontade, não pode ser alienada ${ }^{32} \mathrm{e}$, tampouco, dividida ${ }^{33}$. Tal situação tem sua razão de ser. Sabemos que um indivíduo em pleno gozo dos seus direitos civis pode alienar uma propriedade ou um bem qualquer, mas nos questionamos: como transferir uma vontade? Para Rousseau, caso isso ocorra, incorreremos num erro fatal à cidadania e ao Estado. Em termos do corpo político, cada cidadão tem que ser única e exclusivamente o responsável pela manifestação da sua vontade. Ela não poderá ser delegada a outrem, se assim fosse ela estaria sendo alienada e dividida com esse representante. Aliás, Duguit reforça esse importante aspecto, ao afirmar que

A soberania (...) é uma vontade, eis o ponto fundamental de toda a doutrina... Não que a soberania seja apenas uma [una], mas que ela é indivisível. Isso significa que ela não pode ser dividida em vários componentes e incorporados em corpos separados. Uma vontade é ou não é: ela não pode ser partida. Se a soberania for dividida, haveria fragmentos de vontade, isso é obviamente algo que a mente se recusa a conceber. ${ }^{34}$

Por isso, uma vez que não existe soberania sem vontade, fica evidente o motivo pelo qual ela não poderá ser transmitida. Assim, a soberania requererá um comprometimento

30 SPITZ, Jean-Fabien. La liberté politique: essai de généalogie conceptuelle. Paris: Presses Universitaires de France, 1995, p. 410. (tradução nossa).

${ }^{31}$ Cf. ROUSSEAU, 1995, p. 432.

${ }^{32}$ Cf. Ibidem, p. 368-9. Segundo Derathé, "la souveraineté est un droit inalienable, imprescriptible, incommunicable, qui ne peut rédider que dans le corps de la nation et ne saurait en aucun cas être exercé par un individu". (DERATHÉ, 1970, p. 257). (grifos do autor).

${ }^{33}$ Cf. ROUSSEAU, 1995, p. 369-71.

${ }^{34}$ DUGUIT apud DERATHÉ, 1970, p. 293. (tradução nossa). 
integral do cidadão com a totalidade do corpo político. E esse comprometimento tem que ser, necessariamente, recíproco. Ou seja, todos os cidadãos são responsáveis por si e pelos demais. Outra consequência disso é que os indivíduos, se assim procederem, terão salvaguardado - pelo pacto social - a igualdade e a liberdade.

É desse cenário que parte Spitz para considerar que tal liberdade, salvaguardada pelo pacto social, seja um risco ao próprio cidadão ${ }^{35}$. Acreditamos que o risco de usurpação da liberdade, dada a sociedade ser um ente dinâmico ${ }^{36}$, seja inerente à própria existência do corpo político. Por isso, a elaboração das bases fundantes da sociedade inclui-se aí a vontade geral e a ação do Legislador - são essenciais para que se minimize esse risco que lhe é intrínseco.

Ainda considerando a afirmação de Duguit, a soberania é o laço que efetivamente une os cidadãos à totalidade do corpo político. Do contrário, segundo Rousseau, nenhuma sociedade poderia existir livre e legitimamente; até porque, "só a força do Estado faz a liberdade de seus membros"37. Aí, considerando o aspecto da força do Estado, temos que será desse cenário que surgirão as leis civis, isto é, os limites legais que os cidadãos precisam impor a si mesmos. Assim, depender de outrem, nesse ambiente, não significa abuso ou usurpação, justamente o contrário, é a garantia de que o interesse particular não prevalecerá sobre o coletivo.

Nesse lugar, ambíguo e perigoso da existência coletiva, encontramos a figura do Legislador. Ele é uma peça fundamental na construção e consolidação de um Estado regido por leis. A instituição dessa figura equivaleria ao reconhecimento, por parte dos cidadãos, da dificuldade em transformar a vontade geral em leis e em diretrizes para $\mathrm{o}$ Estado. Assim, partiremos da seguinte premissa: o cidadão comum até sabe o que almeja, mas não saberia determinar com a mesma facilidade os meios para alcançá-lo ${ }^{38}$. É aí que entra em cena a figura excepcional do Legislador. Em linhas gerais, Rousseau qualifica o Legislador e seu contexto de ação nos seguintes termos:

Aquele que ousa empreender a instituição de um povo deve sentir-se com capacidade para, por assim dizer, mudar a natureza humana, transformar cada indivíduo, que por si mesmo é um todo perfeito e solitário, em parte de um todo maior, do qual de certo modo esse indivíduo recebe sua vida e seu ser; alterar a constituição do homem para fortificá-la; substituir a existência física e independente, que todos nós recebemos da natureza, por uma existência parcial e moral. Em uma palavra, é preciso que destitua o homem de suas próprias forças para lhe dar outras que lhe sejam estranhas e das quais não possa fazer uso sem socorro alheio. Na medida em que tais forças naturais estiverem mortas e aniquiladas, mais as adquiridas serão grandes e duradouras, e mais sólida e perfeita a instituição, de modo que, se cada cidadão nada for, nada poderá senão graças a todos os outros, e se a força adquirida pelo todo for igual ou superior à soma das forças naturais de todos os indivíduos, poderemos então dizer que a legislação está no mais alto grau de perfeição que possa atingir. ${ }^{39}$

\footnotetext{
35 “ceux qui sont mis par le pacte social sous la dépendance d'autrui n’ont aucun bénéfice réel”. (SPITZ, 1995, p. 353).

${ }^{36}$ Isto é, susceptível de ter a vontade particular sobrepondo-se à vontade geral. (Cf. ROUSSEAU, 1995, p. 296-7).

${ }^{37}$ Ibidem, p. 394.

${ }^{38}$ Cf. GOYARD-FABRE, Simone. Politique et philosophie dans l'ouvre de Jean-Jacques Rousseau. Paris: PUF, 2001, p. 118.

${ }^{39}$ ROUSSEAU, 1995, p. 381-2.
} 
A partir dessa definição e do contexto em que deverá agir o Legislador, partiremos para a análise das questões que se fazem necessárias para compreender a especificidade dessa figura excepcional e singular no interior de um corpo político.

Já abordamos a estreita dependência entre a soberania e as leis. Doravante, explicaremos como essa relação se constitui e qual a sua relação com outro elemento fundamental ao corpo político em vias de renaturação, a saber, o Legislador. Antes de qualquer coisa, é preciso ter claro que as leis só virão a lume após o pacto social. Não há leis antes disso. Tanto que, para Rousseau foi

Pelo pacto social demos existência e vida ao corpo político. Trata-se, agora, de lhe dar, pela legislação, movimento e vontade, porque o ato primitivo, pelo qual esse corpo se forma e se une, nada determina ainda daquilo que deverá fazer para conservar-se. ${ }^{40}$

É a partir desse momento que se constituirá o sistema de leis que regerá a sociedade nas suas demandas e vicissitudes. Logo, é preciso delimitar quem fará as leis e quem as aplicará. No caso da aplicação das leis, teremos essa responsabilidade delegada ao poder executivo nas figuras dos magistrados e do príncipe ${ }^{41}$. Já a concepção e a configuração das leis fazem parte daquilo que Rousseau designou por poder legislativo. Tal temática tem certa complexidade, pois ela não se refere estritamente ao aspecto da formulação de leis. Se assim fosse, bastaria que se redigisse e publicássemos as leis para que as mesmas se fizessem obedecidas. Sabemos que as leis são emanações da vontade geral com vistas à consecução do bem comum. Mas, nessa formulação temos apenas a gênese e o telos desse sistema de leis. Ainda, falta-nos o "quem" e o "como". Para tanto, precisamos analisar outros "complementos" institucionais necessários à manutenção da soberania popular.

Convém esclarecer que esse Legislador não é, como poderia parecer, um ser humano "superdotado" de alguma qualidade rara no gênero humano. Apesar de que, qualidades tidas como raras ${ }^{42}$ não devem ser desprezadas, quando pensamos nas tarefas que incumbem a essa figura. Rousseau tem diante de si o seguinte quadro:

Para descobrir as melhores regras de sociedade que convenham às nações, precisar-se-ia de uma inteligência superior, que visse todas as paixões dos homens e não participasse de nenhuma delas, que não tivesse nenhuma relação com a nossa natureza e a conhecesse a fundo; cuja felicidade fosse independente de nós e, contudo, quisesse dedicar-se a nós, que, finalmente, almejando uma glória distante, pudesse trabalhar num século e fruí-la em outro. Seriam precisos deuses para dar leis aos homens. ${ }^{43}$

Ao analisarmos essa afirmação pode parecer que se trata efetivamente de um ser superior ou mítico. Até porque, o termo "deuses" aparece no final da citação. Mas não é bem isso. Acreditamos que seja propriamente uma personagem político-social de exceção e com características humanas singulares ${ }^{44}$. Mas, ainda sim um homem.

\footnotetext{
${ }^{40}$ ROUSSEAU, 1995, p. 378.

${ }^{41}$ Cf. Ibidem, p. 396.

${ }^{42}$ Isto é, excelente retórica ou capacidade administrativa fora do comum.

${ }^{43}$ ROUSSEAU, 1995, p. 381.

${ }^{44}$ Cf. MACHADO apud ROUSSEAU, 2000, p. 109.
} 
Destacamos que esse Legislador deverá ter iniciativas e ações que condigam com as efetivas necessidades de um Estado republicano ${ }^{45}$, o qual é fundamentalmente um Estado regido por leis ${ }^{46}$. Ressalvamos que, se esse ator político tiver alguma qualidade superior, isso não deverá ser desprezado; contudo, há que se ter claro que esse não será o fator determinante na sua escolha. A intenção e o conteúdo das suas iniciativas é que são preponderantes para o aparecimento dessa personagem de exceção. Acrescente-se a isso tudo, ele deverá ter uma consciência dos problemas que são comuns ao corpo político e das soluções ou ajustes que se farão necessários. Até por isso faz-se imprescindível que o Legislador, "visse todas as paixões dos homens e não participasse de nenhuma delas". E tudo isso, sem ferir a soberania em nenhum momento. Por isso que, o "legislador, sob todos os aspectos, é um homem extraordinário no Estado" 47 . Contudo, desde já, ressalvamos que extraordinário não equivale a totalitário ou à margem da lei.

Dado esse cenário, estamos diante de uma tarefa que pressupõe a natureza humana e o corpo político como sendo sujeitos a mudanças ou aperfeiçoamentos. Daí que, não podemos ignorar a advertência de Launay: "a essência da política está no seu caráter móvel e flutuante" 48 . O que torna as ações desse Legislador uma arte, a qual não poderá ser regulada pelos cânones institucionais do governo, posto que estes sejam ordinários. Acrescente-se a isso a seguinte situação: o Legislador não é nem soberano e nem governo. Portanto, chegamos a um ponto importante da caracterização e delimitação dessa personagem e de sua relação com as instituições políticas do Estado. Para Rousseau, o Legislador é um "instituidor de povos", cuja resultante será um Estado, isto é, uma associação civil regida por leis ${ }^{49}$. Esse é o quadro geral da questão. Mas, segundo Salinas Fortes, desse quadro geral derivar-se-á dois cenários prováveis para se instituir povos, a saber,

A intervenção do Legislador pode se inserir em dois momentos distintos da vida do povo e assumir duas formas diferentes: seja no início da vida do povo, para instituí-lo, seja perante um povo já com um governo constituído, mas ainda não totalmente corrompido, para reformar o seu governo, detendo o processo de corrupção. ${ }^{50}$

Assim, dada a dinâmica social e a perfectibilidade ${ }^{51}$ humana, o Legislador poderá agir de maneira preventiva ou corretiva. Isto é, a corrupção humana poderá ser contornada ou no início da formação do corpo político ou numa fase em que a corrupção ainda não tenha degenerado a maior parte do Estado ${ }^{52}$. O que implica na seguinte constatação: nem todos os povos são suscetíveis à ação preventiva ou corretiva do Legislador.

Diante dessa tarefa, fica evidente o motivo pelo qual o Genebrino configura tal personagem como sendo excepcional. Para Rousseau, esse é um empreendimento que

\footnotetext{
${ }^{45}$ Republicano no sentido de regime de leis, mas não na forma específica do regime republicano.

46 “J'appelle donc République tout Etat régi par des lois, sous quelque forme d'administration que ce puisse être: car alors seulement l'intérêt public gouverne, et la chose publique est quelque chose. Tout gouvernement légitime est républicain”. (ROUSSEAU, 1995, p. 379-80).

${ }^{47}$ Ibidem, p. 382.

48 LAUNAY, Michel. Jean-Jacques Rousseau, écrivain politique. Grenoble-Cannes: CEL/ACER, 1971, p. 253. (tradução nossa).

${ }^{49}$ Cf. ROUSSEAU, 1995, p. 297.

${ }^{50}$ FORTES, Luiz Roberto Salinas. Rousseau: da teoria à prática. São Paulo: Ática, 1976, p. 123.

${ }^{51}$ Rousseau delimita a perfectibilidade como sendo uma singularidade específica do gênero humano, a qual será capaz de ajudar-nos a esclarecer o processo lento e gradual de desenvolvimento da desigualdade e da corrupção entre os homens e a possibilidade de efetivar a renaturação.

52 Cf. SPITZ, 1995, p. 393.
} 
implica em muita ousadia; posto que a meta visada pressuponha uma mudança que colocará em cena a figura do homem e da sua natureza. Temos justamente aqui um das formulações em que nos apoiamos para defender que a renaturação é uma possibilidade política real - "para, por assim dizer, mudar a natureza humana"53. Tal mudança na natureza humana, não é uma perversão ou corrupção da mesma. Visa-se com tal alteração encontrar meios legais e institucionais para fortalecer certos aspectos da "constituição humana" 54 . Tal reforço poderá ser constatado na manutenção e ampliação da liberdade e da igualdade no interior do corpo social. Por isso que, segundo Machado, "o Legislador é (...) alguém consciente desse processo necessário e fundamental, que se dispõe a estimulá-lo, facilitá-lo e até completá-lo pelas instituições" ${ }^{55}$. Além do que, essa renaturação visará manter certas qualidades da natureza humana em concerto com as demandas político-sociais do Estado soberano.

Convém reforçar que o Legislador não se põe acima da vontade geral. Por isso, ele não é de fato nem soberano e nem governo. Apesar de vinculado ao poder legislativo, o raio de atuação do Legislador tem certos limites importantes. Portanto, Rousseau propõe a restrição do papel legislativo desse indivíduo excepcional: "aquele que redige as leis não tem e não deve ter nenhum direito legislativo" "56. Assim, vemos que não há transferência da vontade geral dos cidadãos para essa figura excepcional. Haja vista que se preserva a autonomia dos cidadãos - via vontade geral - em exercer o poder legislativo. Por conta dessa situação, Derathé acrescenta que "o poder legislativo (...) consiste em duas coisas inseparáveis: fazer as leis e mantê-las" "57. Vale relembrar que a vontade não pode ser alienada, pois, trata-se de um direito incomunicável ${ }^{58}$. Logo, como é possível ao Legislador "fazer as leis" se o mesmo não tem em suas mãos o poder legislativo? O próprio Genebrino coloca essa problemática nos seguintes termos: "na obra da legislação encontramos, ao mesmo tempo, dois elementos que parecem incompatíveis: uma empresa acima das forças humanas e, para executá-la, uma autoridade que nada $e^{n, 59}$. Em face dessa questão, Salinas Fortes nos adverte que não podemos considerar o Legislador e a sua obra desvinculadas da sociedade e do contrato social. Por esse motivo, "o corpo político não preexiste (...) a ação do Legislador, guardando com ela uma anterioridade lógica e não-cronológica" ${ }^{\circ 0}$. Nesse aspecto a tarefa do Legislador não se desvincula das necessidades do povo que recebe sua orientação. Mas, tal orientação não requer que o Legislador tenha algum tipo de poder legislativo especial. Se o tivesse, significaria que os cidadãos teriam alienado ou dividido o poder soberano. Logo, poriam por terra a soberania do corpo político. Aí, sem corpo político não faria sentido tratarmos dos aspectos inerentes a tal figura excepcional. Além do mais, o Legislador não é, também, um membro do poder executivo. Posto que o executivo seja um elemento ordinário na condução da coisa pública.

O Legislador é um indivíduo excepcional e extraordinário que agirá se respaldando em sua sabedoria e prudência. Nesse aspecto, Burgelin nos aponta que " $a$ sua sabedoria está em seguir os costumes e intervir com grande discernimento,

\footnotetext{
53 “Celui qui ose entreprendre d'instituer un peuple doit se sentir en état de changer, pour ainsi dire, la nature humaine". (ROUSSEAU, 1995, p. 381).

54 “...d'altérer la constitution de l'homme pour la renforcer”. (Ibidem, p. 381).

${ }^{55}$ MACHADO apud ROUSSEAU, 2000, p. 110.

${ }^{56}$ ROUSSEAU, 1995, p. 383.

${ }^{57}$ DERATHÉ, 1970, p. 303. (tradução nossa).

${ }^{58}$ Cf. ROUSSEAU, 1995, p. 383.

${ }^{59}$ Ibidem, p. 383.

${ }^{60}$ FORTES, 1976, p. 94.
} 
conforme o caso; sem pretender procurar um bem absoluto imediato" ${ }^{61}$. Por isso que a soberania sempre permanecerá nas mãos dos cidadãos e não nas do Legislador ${ }^{62}$. Daí ele ser, essencialmente, um orientador ou guia da soberania do povo. Entretanto, como já afirmamos anteriormente, essa orientação tem limites e um deles refere-se a existência ou não de aptidão desse povo a um novo sistema de leis que seja afim com o interesse geral do corpo político.

Enfim, as leis devem ser a expressão da vontade política dos cidadãos. Mas, um corpo político não é somente vontade, é também movimento ${ }^{63}$. O que denota uma sociedade dinâmica diante das suas diversas instituições sociais e políticas; as leis civis deverão responder a essa importante demanda. Posto que as leis devem balizar o agir cotidiano dos cidadãos e do governo. Dado esse aspecto central das leis alguns intérpretes colocam-na como oriunda dos homens, mas superior a estes. Temos, então, uma situação inusitada e aparentemente paradoxal, ou seja, as leis deverão estar acima dos cidadãos e emanar destes. Para Cassirer, a "lei como tal não possui poder limitado, e sim absoluto; ela simplesmente ordena e exige de maneira incondicional" 64 . Falamos acima em movimento e vontade, aqui Cassirer expressa adequadamente a lei como expressão da vontade soberana do povo. Aliás, soberana e incondicional. É por isso que Silva sustenta que a "solução estaria na edificação de uma força exterior impessoal, representada pela lei, fundada na razão e nascida da combinação entre os indivíduos colocados sob sua direção"65. Essa força exterior é o próprio Estado republicano e regido por leis. Ao Legislador caberá instituir as leis que deem conta desse movimento da sociedade e das prováveis fontes de desvirtuamento do interesse geral ${ }^{66}$.

Vimos que a igualdade e a liberdade são necessárias aos membros do corpo político, assim como o Legislador é necessário ao corpo político ${ }^{67}$. Isso implica em dizer que tal situação requer uma análise da codeterminação entre o povo e o Legislador, ou dizendo de outra maneira, no Estado republicano, a existência de um implica na do outro. Podemos resumir o que acabamos de dizer da seguinte maneira: "os particulares discernem o bem que rejeitam; o público quer o bem que não discerne. Todos necessitam, igualmente de guias" 68 . Isto é, para que a vontade geral torne-se soberana há que se convergir os interesses particulares dissonantes em prol do bem comum $^{69}$. E isso é valido para a totalidade do Estado, ou seja, cidadãos, Legislador, príncipe, magistrados e todos os outros que se fizerem necessários ao corpo político. Pois, o Legislador será guiado pelo povo - via vontade geral. O Legislador, por meio da instituição das leis, guiará povo e os magistrados. Os magistrados agirão no sentido de atender as demandas ordinárias do governo. Por isso que, todos dependem e precisam de todos.

Por fim, diante desse cenário, salientamos que, o Legislador não pode se igualar ou se sobrepor à vontade geral. De acordo com Salinas Fortes, "Ao Legislador caberá

\footnotetext{
${ }^{61}$ BURGELIN, P. La Philosophie de l'Existence de Jean-Jacques Rousseau. Paris: PUF, 1952, p. 564. (tradução nossa).

${ }^{62}$ Cf. MASTERS, 1968, p. 355.

63 "Par le pacte social nous avons donné l'existence et la vie au corps politique: il s'agit maintenant de lui donner le mouvement et la volonté par la législation”. (ROUSSEAU, 1995, p. 378).

${ }^{64}$ CASSIRER, 1999, p. 94.

65 SILVA. F. B. Os Princípios do Contrato Social e as constituições da Córsega e da Polônia. In: Notandum Libro 10, p. 32.

${ }^{66}$ Cf. ROUSSEAU, 1995, p. 378; ver: GOYARD-FABRE, 2001, p. $48-9$.

${ }^{67}$ Cf. ROUSSEAU, 1995, p. 381-4.

${ }^{68}$ Ibidem, p. 380.

69 "seulement, quoique la volonté générale, en sa rectitude rationnelle formelle, ne puisse errer, le peuple ne voit pas toujours le bien que, pourtant, il veut; et, quand il le voit, il ne le fait pas toujours". GOYARD-FABRE, 2001, p. 118.
} 
esta difícil tarefa: a conservação do corpo político é o objeto da 'ciência da legislação" "70. Essa ciência da legislação é uma ciência da sabedoria e da prudência ${ }^{71}$. Isso, contudo, tem um sério problema: ao guiar-se pela prudência, o Legislador não se tornaria refém da vontade popular ou tornaria o povo refém da sua? Tal questão reforça a necessidade de compreendermos o papel fundamental do Legislador, a saber, garantir a consecução do interesse geral expressando-o nas leis. Caso contrário, essa figura excepcional tornar-se-ia um mero joguete da pluralidade de interesses privados contrastantes. Ou, um tirano.

\section{Referências}

BIGNOTTO, Newton. As aventuras da virtude: as ideias republicanas na França do século XVIII. São Paulo: Companhia das Letras, 2010.

BURGELIN, P. La Philosophie de l'Existence de Jean-Jacques Rousseau. Paris: PUF, 1952. CASSIRER, Ernst. A questão Jean-Jacques Rousseau. São Paulo: Editora Unesp, 1999.

DERATHÉ, R. Jean-Jacques Rousseau et la science politique de son temps. Paris, Vrin, 1970.

FORTES, Luiz Roberto Salinas. Rousseau: da teoria à prática. São Paulo: Ática, 1976.

GOLDSCHMIDT, Victor. Anthropologie et politique: les principes du système de Rousseau. Paris, Vrin, 1983.

GOYARD-FABRE, Simone. Politique et philosophie dans l'œuvre de Jean-Jacques Rousseau. Paris: PUF, 2001.

LAUNAY, Michel. Jean-Jacques Rousseau, écrivain politique. Grenoble-Cannes: CEL/ACER, 1971.

MASTERS, Roger D. The political philosophy of Rousseau. Princeton: Princeton University Press, 1968.

ROUSSEAU, Jean-Jacques. Textos escolhidos/Rousseau. Trad. de Lourdes Santos Machado. São Paulo: Nova Cultural, 2 vol., 2000.

Du contrat social. Edição comentada por Maurice Halbwachs. Paris: AubierMontaigne, 1943.

Fontes, 1999.

Emílio ou Da Educação. Tradução de Roberto Leal Ferreira. São Paulo: Martins

. Obras de Jean-Jacques Rousseau. Obras Políticas I. Rio de Janeiro, Porto Alegre e São Paulo: Editora Globo, 1958.

Oeuvres Complètes. Bernard Gagnebin e Marcel Raymond (orgs). Paris: PléiadeGallimard, 5 vol., 1959-1995.

3 vol., 1971.

Oeuvres Complètes. Jean Fabre e Michel Launay (orgs). Paris: L’Intégrale-Du Seuil,

SILVA, Fábio de Barros. Os Princípios do Contrato Social e as constituições da Córsega e da Polônia. In: Notandum Libro 10, 2008.

SPITZ, Jean-Fabien. La liberté politique: essai de généalogie conceptuelle. Paris: Presses Universitaires de France, 1995.

TALMON. Jacob Leib. Los orígenes de la democracia totalitária. Madrid: Aguillar, 1956.

${ }^{70}$ FORTES, 1976, p. 93. (grifo do autor).

71 "Prudential science". (Cf. MASTERS, 1968, p. 563-5. 